Archived version from NCDOCKS Institutional Repository http://libres.uncg.edu/ir/asu/

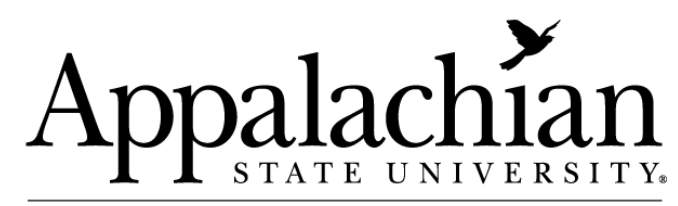

B O O N E, NORT H C A R O L I A

\title{
Immune And Oxidative Changes During And Following The Western States Endurance Run
}

\author{
By: D.C. Nieman, C.I. Dumke, D.A. Henson, S.R. McAnulty, \\ L.S. McAnulty, R.H. Lind, \& J.D. Morrow
}

\begin{abstract}
Changes in immune and oxidative stress parameters were measured in ultramarathon runners competing in the $160-\mathrm{km}$ Western States Endurance Run. Forty-five runners agreed to provide blood and saliva samples the morning before the race event, at the $90-\mathrm{km}$ aid station, and 5 - $10 \mathrm{~min}$ post-race. Upper respiratory tract infection (URTI) during the two-week period post-race was assessed retrospectively by telephone interviews. Forty subjects completed 90-km (race time, $13.1 \pm 0.3 \mathrm{~h}$ ), and 31 completed the 160-km race event (27.0 $\pm 0.4 \mathrm{~h})$. The blood neutrophil and monocyte counts rose $249 \%$ and $214 \%$, respectively, in the 31 finishers. Salivary $\operatorname{lgA}$ (slgA) secretion rate decreased significantly from $508 \pm 40 \mu \mathrm{g} / \mathrm{min}$ pre-race, to $287 \pm 39 \mu \mathrm{g} / \mathrm{min}$ at $90-\mathrm{km}$, and $254 \pm$ $30 \mu \mathrm{g} / \mathrm{min}$ post-race (50\% decrease). Significant increases were measured in cytokines at $90-\mathrm{km}$ and post-race, with post-race IL-1 0 increasing 9.5-fold, IL- 1 ra 6.1 -fold, IL-6 50.2-fold, and IL-8 2.5-fold over pre-race levels. Post-race indicators of oxidative stress, F2-isoprostane and lipid hydroperoxides, increased $33 \%$ and $88 \%$, respectively. Pearson product-moment correlations revealed positive correlations at $90-\mathrm{km}$ between F2-isoprostane and IL-6 ( $r=0.31, p=0.048)$, IL-10 ( $r=0.31, p=0.050)$, and IL-8 ( $r=0.43, p=0.005)$, but no other significant relationships between immune and oxidative stress indicators at 90-km and post-race. In the group of runners completing at least $90 \mathrm{~km}$ of the race, $26 \%$ reported an URTI episode during the two-week period postrace. A low slgA secretion rate at $90-\mathrm{km}$ was the best predictor of post-race URTI (173 $\pm 34 \mu \mathrm{g} / \mathrm{min}$ in those who later acquired URTI compared to $325 \pm 40 \mu \mathrm{g} / \mathrm{min}$ in those without URTI, $p=0.007$ ). In conclusion, a modest correlation was found between cytokines and F2-isoprostane at $90-\mathrm{km}$ when the greatest oxidative stress occurred, but no other significant correlations in immune and oxidative stress indicators during and following a 160-km ultramarathon race event were noted. About one in four ultramarathoners reported URTI during the two-week period post-race, and a low slgA secretion rate mid-race best predicted URTI occurrence.
\end{abstract}

Nieman, D. C.; Dumke, C. I.; Henson, D. A.; McAnulty, S. R.; McAnulty, L. S.; Lind, R. H.; Morrow, J. D. (2003). Immune and Oxidative Changes During and Following the Western States Endurance Run. Int J Sports Med 2003; 24(7): 541-547. DOI: 10.1055/s-2003-42018. Publisher version of record available at: https://www.thiemeconnect.com/products/ejournals/abstract/10.1055/s-2003-42018 


\section{C. Nieman ${ }^{1}$ \\ C. I. Dumke ${ }^{1}$ \\ D. A. Henson ${ }^{1}$}

S. R. McAnulty ${ }^{1}$

L. S. McAnulty ${ }^{1}$

R. H. Lind ${ }^{1}$

J. D. Morrow ${ }^{2}$

\section{Immune and Oxidative Changes During and Following} the Western States Endurance Run

\begin{abstract}
Changes in immune and oxidative stress parameters were measured in ultramarathon runners competing in the $160-\mathrm{km}$ Western States Endurance Run. Forty-five runners agreed to provide blood and saliva samples the morning before the race event, at the $90-\mathrm{km}$ aid station, and 5-10 min post-race. Upper respiratory tract infection (URTI) during the two-week period postrace was assessed retrospectively by telephone interviews. Forty subjects completed 90-km (race time, $13.1 \pm 0.3 \mathrm{~h}$ ), and $31 \mathrm{com}$ pleted the $160-\mathrm{km}$ race event $(27.0 \pm 0.4 \mathrm{~h})$. The blood neutrophil and monocyte counts rose $249 \%$ and $214 \%$, respectively, in the 31 finishers. Salivary IgA (sIgA) secretion rate decreased significantly from $508 \pm 40 \mu \mathrm{g} / \mathrm{min}$ pre-race, to $287 \pm 39 \mu \mathrm{g} / \mathrm{min}$ at $90-\mathrm{km}$, and $254 \pm 30 \mu \mathrm{g} / \mathrm{min}$ post-race ( $50 \%$ decrease). Significant increases were measured in cytokines at 90-km and post-race, with post-race IL-10 increasing 9.5-fold, IL-1ra 6.1-fold, IL-6 50.2-fold, and IL-8 2.5-fold over pre-race levels. Post-race indicators of oxidative stress, $\mathrm{F}_{2}$-isoprostane and lipid hydroperoxides, increased $33 \%$ and $88 \%$, respectively. Pearson product-moment correlations revealed positive correlations at $90-\mathrm{km}$ between
\end{abstract}

$\mathrm{F}_{2}$-isoprostane and IL-6 $(\mathrm{r}=0.31, \mathrm{p}=0.048), \quad \mathrm{IL}-10 \quad(\mathrm{r}=0.31$, $\mathrm{p}=0.050)$, and IL-8 $(\mathrm{r}=0.43, \mathrm{p}=0.005)$, but no other significant relationships between immune and oxidative stress indicators at $90-\mathrm{km}$ and post-race. In the group of runners completing at least $90 \mathrm{~km}$ of the race, $26 \%$ reported an URTI episode during the two-week period post-race. A low sIgA secretion rate at 90$\mathrm{km}$ was the best predictor of post-race URTI $(173 \pm 34 \mu \mathrm{g} / \mathrm{min}$ in those who later acquired URTI compared to $325 \pm 40 \mu \mathrm{g} / \mathrm{min}$ in those without URTI, $p=0.007$ ). In conclusion, a modest correlation was found between cytokines and $\mathrm{F}_{2}$-isoprostane at $90-\mathrm{km}$ when the greatest oxidative stress occurred, but no other significant correlations in immune and oxidative stress indicators during and following a $160-\mathrm{km}$ ultramarathon race event were noted. About one in four ultramarathoners reported URTI during the two-week period post-race, and a low slgA secretion rate midrace best predicted URTI occurrence.

\section{Key words}

Oxidative stress · salivary IgA - upper respiratory tract infection . isoprostanes · cytokines

\section{Introduction}

Many components of the immune system exhibit adverse change after prolonged, heavy exertion [17-25,30-32]. The changes in immunity are greater following competitive marathon/ultramarathon race events compared to laboratory treadmill runs of $2.5-3 \mathrm{~h}[17-20,31]$. These immune changes occur in several compartments of the immune system and body (e.g., the skin, upper respiratory tract mucosal tissue, lung, blood, and muscle) [17]. This period of altered immunity lasts 3 to $72 \mathrm{~h}$ depending on the immune measure, and may in part explain the observed increase in risk of subclinical and clinical upper respiratory tract infection (URTI) [17-21]. The increase in post-exertion URTI risk may be amplified when other factors related to immune function are present, including exposure to novel pathogens during travel, lack of sleep, severe mental stress, malnutrition, or

${ }^{1}$ Departments of Health, Leisure, and Exercise Science; Biology; Family and Consumer Sciences; Appalachian State University, Boone, North Carolina, USA

2 Departments of Medicine and Pharmacology, Vanderbilt University School of Medicine, Nashville, Tennesse, USA

Correspondence

D. C. Nieman, Dr.PH, FACSM - Department of Health \& Exercise Science · Appalachian State University · Boone · North Carolina $28608 \cdot$ USA

Phone: +1 8282626318 ·Fax: +1 8282623138 ·E-Mail: niemandc@appstate.edu 
weight loss $[9,10,17]$. Most attempts to link exercise-induced immune changes with URTI incidence have failed, although reduced sIgA levels have shown some predictive value $[9,10,18,20]$.

The production of reactive oxygen species (ROS) during exhaustive exercise is well established [1,2,12-14,27,34]. ROS generation and antioxidant status have been linked to immune alterations in certain disease states $[8,11,29]$ and the aging process [6], but this relationship is largely unstudied within the context of human athletic endeavor $[3,14,15,19,33] . \mathrm{F}_{2}$-isoprostanes are stable prostaglandin-like compounds produced by free radical catalysed peroxidation of arachidonic acid, independent of the cyclooxygenase pathway, and possess potent biological activity such as vasoconstriction of smooth muscles and stimulation of platelet aggregation $[16,26]$. $\mathrm{F}_{2}$-isoprostanes increase intracellular calcium levels in cells expressing thromboxane receptors, and may thus influence or modulate the immune function. In a recent study of 28 ultramarathon runners, however, we were unable to demonstrate a significant correlation between immune measures and $\mathrm{F}_{2}$-isoprostane during or following an $80-\mathrm{km}$ race except for a weak relationship with plasma interleukin (IL)-10 $(r=0.42, p=0.026)$ [19]. IL-10 has emerged as an anti-inflammatory cytokine with antioxidant properties, and has been hypothesized to play a role in gene expression and the biosynthesis of oxidative stress-related cofactors, such as ROS and inflammatory cytokines [11].

We have previously reported on plasma cytokine and salivary IgA changes following competitive marathon and ultramarathon events [17-20,22,25]. In these studies, no difference in the pattern of change in cytokines and sIgA was found for males and females, or for younger and older runners. We also observed that the increase in plasma cytokine levels and the decrease in sIgA secretion rate following ultramarathon events (80- and $90-\mathrm{km}$ ) were comparable to what we had measured following $42.2-\mathrm{km}$ marathon race events.

In this study, we sought to extend these findings to a much more rigorous setting, the high-altitude, $160-\mathrm{km}$ Western States Endurance Run. We hypothesized that the increase in plasma cytokine levels and the decrease in sIgA secretion rate would not differ between male and female, or younger and older ultramarathon runners, and that perturbations would be similar to those reported previously by our research team in runners competing in 42.2-km marathon race events. We also related plasma cytokine and slgA secretion rate changes to oxidative stress and post-race URTI incidence to test the hypothesis that these are linked to some degree.

\section{Material and Methods}

\section{Subjects and race description}

Forty-five experienced ultramarathoners were recruited, and included both males and females without age restriction. Informed consent was obtained from each subject, and the experimental procedures were in accordance with the policy statements of the institutional review board of the Appalachian State University. To enter the study, subjects must have completed a $160-\mathrm{km}$ race, and be qualified for the 160-km Western States Endurance Run (held June 29, 2002). To qualify for the Western States Endurance Run, runners must have completed a $160-\mathrm{km}$ race in under $24 \mathrm{~h}$, or a $100-\mathrm{km}$ race in $12-13 \mathrm{~h}$, depending on age.

The 160-km Western States Endurance Run is a point-to-point trail run in the Sierra Nevada Mountains of northern California, and is regarded as one of the most arduous organized running events in the United States. The race starts at Squaw Valley, California ( $1890 \mathrm{~m}$ altitude), and finishes at Auburn, California $(366 \mathrm{~m})$. The trail race course ascends $777 \mathrm{~m}$ to Emigrant Pass ( $2668 \mathrm{~m}$, the highest point) within the first $7 \mathrm{~km}$ and then passes through remote and rugged territory to Auburn. The total altitude gain and loss during the race is $5500 \mathrm{~m}$ and $6700 \mathrm{~m}$, respectively. The race starts at 5:00 am, and runners must reach the finish line within $30 \mathrm{~h}$ to be eligible for an award. Up to half of the trail may be traveled by some runners at night. A staff of over 1300 volunteers supports the runners and works 26 aid stations, including 11 medical check points.

\section{Research design and infection history}

Subjects provided blood and saliva samples during registration, held the morning before the race. Pre-race body mass and skinfold thicknesses at three sites (chest, abdomen, thigh for men, and triceps, suprailliac, and thigh for women) were measured, and subjects filled in a questionnaire on basic demographics and training history. On race day, body mass, blood samples, and saliva samples were collected at the $90-\mathrm{km}$ aid station (Michigan Bluff, $1220 \mathrm{~m}$ ) and within 5-10 min post-race at Auburn. Following the race, subjects with heart rate monitors were asked to provide mean heart rates prior to the $90-\mathrm{km}$ aid station and the finish of the race. Subjects consumed food and beverages ad libitum during the race.

Two weeks post-race, each runner was interviewed over the telephone regarding symptoms of upper respiratory tract infection. The following health problems were recorded, in accordance with previous investigations by our research team [18]: 1 . No health problems; 2 . Cold symptoms (runny, stuffy nose, sore throat, coughing, sneezing, colored discharge); 3 . Flu symptoms (fever, headache, general aches and pains, fatigue and weakness, chest discomfort, cough); 4. Nausea, vomiting, and/or diarrhea; 5. Muscle, joint, or bone problems/injury; 6 . Other health problems (describe). An URTI episode was recorded if cold or flu symptoms persisted for two days or longer.

\section{Blood cell counts}

Blood samples were drawn from an antecubital vein with subjects in the seated position. Routine complete blood counts (CBC) and comprehensive diagnostic chemistries were performed by a clinical hematology laboratory, and provided leukocyte subset counts, hemoglobin, and hematocrit. Plasma volume changes were estimated using the method of Dill and Costill [7].

\section{Cytokine measurements}

Total plasma concentrations of interleukin- 1 receptor antagonist (IL-1ra), interleukin-6 (IL-6), interleukin-8 (IL-8), and interleukin-10 (IL-10) were determined using quantitative sandwich ELISA kits provided by R\&D Systems, Inc. (Minneapolis, MN). All samples and provided standards were analyzed in duplicate. A 
high sensitivity kit was used to analyze IL-6 in the pre-race plasma samples. A standard curve was constructed using standards provided in the kits and the cytokine concentrations were determined from the standard curves using linear regression analysis. The assays were a two-step "sandwich" enzyme immunoassay in which samples and standards were incubated in a 96-well microtiter plate coated with polyclonal antibodies for the test cytokine as the capture antibody. Following the appropriate incubation time, the wells were washed and a second detection antibody conjugated to either alkaline phosphatase (IL-6 high sensitivity) or horseradish peroxidase (IL-1ra, IL-6, IL-8, IL-10) was added. The plates were incubated and washed, and the amount of bound enzyme-labeled detection antibody was measured by adding a chromogenic substrate. The plates were then read at the appropriate wavelength (450 minus $570 \mathrm{~nm}$ for IL1ra, IL-6, IL-8, IL-10; 490 minus $650 \mathrm{~nm}$ for IL-6 high sensitivity). The minimum detectable concentration of IL- $1 \mathrm{ra}$ was $<22 \mathrm{pg} / \mathrm{ml}$, IL- $6<0.70 \mathrm{pg} / \mathrm{ml}$, IL-6 high sensitivity $<0.094 \mathrm{pg} / \mathrm{ml}$, IL- $8<10 \mathrm{pg} /$ $\mathrm{ml}$, and IL- $10<3.9 \mathrm{pg} / \mathrm{ml}$.

\section{Salivary samples}

Unstimulated saliva was collected for four minutes by expectoration into $15-\mathrm{ml}$ plastic, sterilized vials. Participants were urged to pass as much saliva as possible into the vials during the 4-min timed session. The saliva samples were frozen in dry ice following collection, and then stored at $-80^{\circ} \mathrm{C}$ until analysis. Saliva volume was measured to the nearest $0.1 \mathrm{ml}$, and saliva total protein was quantified using the Coomassie ${ }^{\circledR}$ protein assay reagent, a modification of the Bradford [5] Coomassie ${ }^{\circledR}$ dye binding colorimetric method. Salivary IgA ( $\operatorname{IgA}$ ) was measured by enzyme linked immunosorbent assay according to the procedures of the Hunter Immunology Unit (Royal Newcastle Hospital, Newcastle, NSW, Australia) $[9,10]$. The data were expressed as concentration of slgA $\left(\mu \mathrm{g} \times \mathrm{ml}^{-1}\right)$, concentration of sIgA relative to total protein concentration $\left(\mu \mathrm{g} \times \mathrm{mg}^{-1}\right)$, and slgA secretion rate $\left(\mu \mathrm{g} \times \mathrm{min}^{-1}\right)$.

\section{Oxidative measurements}

Blood samples were drawn into heparinized vacutainer tubes. The tubes were placed on ice and then spun at $10000 \mathrm{~g}$ for $10 \mathrm{~min}$. The plasma was immediately alliquoted into cryotubes, frozen on dry ice, and stored at $-80^{\circ} \mathrm{C}$ until analysis. Plasma $\mathrm{F}_{2}-$ isoprostanes were determined using gas chromatography mass spectrometry at Vanderbilt University according to the methodology of Morrow and Roberts [16].

Lipid hydroperoxides were determined after extraction using spectrophotometric analysis (Cayman Chemical, Ann Arbor, MI). Briefly, $100 \mu$ l of plasma sample were pipetted into duplicate test tubes, and $100 \mu$ l of extract $R$ (kit reagent) saturated methanol (Fisher Scientific, Pittsburgh, PA) were added to each tube. All tubes were then vortexed, and then $750 \mu$ of cold chloroform (Fisher Scientific, Pittsburgh, PA) were added to each test tube, and the tubes were vortexed again. All tubes were centrifuged at $1500 \mathrm{~g}, 4^{\circ} \mathrm{C}$ for five minutes, and $500 \mu \mathrm{l}$ of the bottom chloroform layer were extracted from each tube and immediately placed in ice. Next, $450 \mu$ l of a $2: 1$ ratio deoxygenated chloroform-methanol mixture were added to each tube, and the tubes were vortexed. A standard curve was prepared using a kitprovided hydroperoxide standard and varying amounts of the $2: 1$ ratio deoxygenated chloroform-methanol mixture giving a

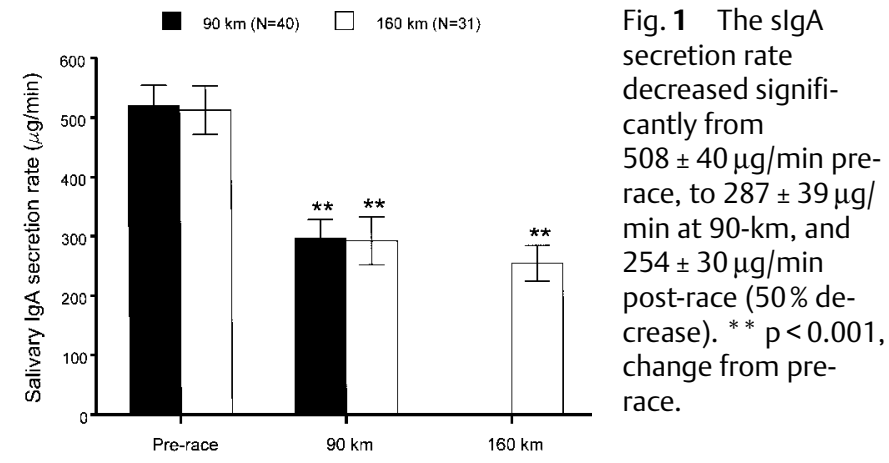

range of zero to $5 \mathrm{nM}$ and a total volume of $950 \mu \mathrm{l}$. Fifty $\mu \mathrm{l}$ of a kit provided chromogen were added to each sample and standard in duplicate, and the tubes were vortexed. All tubes were incubated at room temperature for five minutes, and then $300 \mu \mathrm{l}$ of each standard and sample were removed and placed in a 96-well glass plate and read at $500 \mathrm{~nm}$. Lipid hydroperoxide concentration was determined from a linear regression line generated from the standard curve.

Total plasma antioxidant potential was determined by the ferric reducing antioxidant potential (FRAP) assay according to the methodology of Benzie and Strain [4]. The working FRAP solution was prepared daily and consisted of $300 \mathrm{mmol}$ per liter acetate buffer with the $\mathrm{pH}$ adjusted to 3.6 (3.1 grams sodium acetate, Sigma, St. Louis, MO) and $16 \mathrm{~mL}$ of $1 \mathrm{~N}$ acetic acid (Sigma, St. Louis, MO) per liter of buffer solution; $10 \mathrm{mmol}$ per liter TPTZ (2,4,6-tripyridyl-s-triazine, Sigma, St. Louis, MO) in $40 \mathrm{mmol}$ per liter $\mathrm{HCl}$ (Fisher Scientific, Pittsburgh, PA); $20 \mathrm{mmol}$ per liter iron trichloride hexahydrate (Sigma, St. Louis, MO) in DI water. The FRAP reagent was prepared as required by mixing $25 \mathrm{~mL}$ acetate buffer, $2.5 \mathrm{~mL}$ TPTZ solution, and $2.5 \mathrm{~mL}$ iron trichloride hexahydrate solution. The FRAP solution was placed in a water bath, warmed to $37^{\circ} \mathrm{C}$, and $100 \mu \mathrm{l}$ of either standard, sample, and blank (DI water), respectively were added to glass test tubes containing $3.0 \mathrm{~mL}$ of warmed FRAP reagent and vortexed. All tubes were then incubated at $37^{\circ} \mathrm{C}$ for 4 min and read at $593 \mathrm{~nm}$. Samples and standards were analyzed in duplicate, and FRAP values were expressed as ascorbic acid equivalents as determined by linear regression from an ascorbic acid standard curve $(0-$ $1000 \mu \mathrm{M})$.

\section{Statistical analysis}

Data are expressed as mean $\pm \mathrm{SE}$. Changes from pre-race levels for the $90-\mathrm{km}$ and post-race values were assessed for the entire group using paired t-tests. For these two comparisons across time, a Bonferroni adjustment was made, with statistical significance set at $\mathrm{p}<0.025$. Pearson product-moment correlations were used to test the relationship between $90-\mathrm{km}$ and post-race oxidative stress and immune measures. Ultramarathon runners were divided into URTI and non-URTI groups, and differences in immune and oxidative stress indicators were compared between these groups using independent t-tests. 
Table 1 Subject characteristics ( $\mathrm{n}=31 ; 22$ males, 9 females) (mean $\pm \mathrm{SE}$; range)

\begin{tabular}{|lll}
\hline Variable & Mean \pm SE & Range \\
\hline Age $(\mathrm{y})$ & $46.9 \pm 1.5$ & $33-65$ \\
\hline Height $(\mathrm{m})$ & $1.73 \pm 0.02$ & $1.50-1.88$ \\
\hline Pre-race body mass $(\mathrm{kg})$ & $66.1 \pm 2.1$ & $45.4-88.5$ \\
\hline 90-km (kg) & $67.4 \pm 2.0$ & $47.6-89.8$ \\
\hline 160-km (kg) & $66.8 \pm 2.0$ & $47.6-89.4$ \\
\hline Sum of 3 skinfolds (mm) & $43.3 \pm 1.9$ & $22.5-67.0$ \\
\hline Running history (y) & $15.4 \pm 1.3$ & $2.5-30.0$ \\
\hline Ultramarathons raced (number) & $51.6 \pm 10.3$ & $5-306$ \\
\hline Running distance (km/week) & $82.3 \pm 4.5$ & $48.3-161.0$ \\
\hline Race time, 90-km (h) & $13.1 \pm 0.3$ & $10.2-15.8$ \\
\hline Race time, 160-km (h) & $27.0 \pm 0.4$ & $20.3-29.9$ \\
\hline Heart rate, 90-km (beats/min) & $133 \pm 4$ & $110-155$ \\
\hline Heart rate, 160-km (beats/min) & $108 \pm 6$ & $80-160$ \\
\hline
\end{tabular}

Table 2 Leukocyte subset counts $(\mathrm{N}=31)($ mean $\pm \mathrm{SE})$

\begin{tabular}{llll}
\hline Variable $(\mathbf{1 0} \boldsymbol{9} / \mathbf{l})$ & Pre-race & $\mathbf{9 0 - k m}$ & $\mathbf{1 6 0 - k m}$ \\
\hline Total leukocytes & $5.37 \pm 0.26$ & $16.8 \pm 0.6^{* *}$ & $14.3 \pm 0.6^{* *}$ \\
\hline Neutrophils & $3.27 \pm 0.21$ & $13.6 \pm 0.6^{* *}$ & $11.4 \pm 0.5^{* *}$ \\
\hline Lymphocytes & $1.61 \pm 0.08$ & $1.89 \pm 0.11^{* *}$ & $1.66 \pm 0.51$ \\
\hline Monocytes & $0.35 \pm 0.02$ & $1.16 \pm 0.07^{* *}$ & $1.10 \pm 0.06^{* *}$ \\
\hline Eosinophils & $0.12 \pm 0.02$ & $0.07 \pm 0.01^{*}$ & $0.05 \pm 0.01^{* *}$ \\
\hline Basophils & $0.03 \pm 0.003$ & $0.02 \pm 0.004$ & $0.03 \pm 0.004$ \\
\hline
\end{tabular}

${ }^{*} \mathrm{p}<0.01,{ }^{* *} \mathrm{p}<0.001$, change from pre-race.

Table 3 Salivary $\lg A(N=31)($ mean $\pm S E)$

\begin{tabular}{llll}
\hline Variable & Pre-race & $\mathbf{9 0 - k m}$ & $\mathbf{1 6 0 - k m}$ \\
\hline $\begin{array}{l}\text { Saliva secretion rate } \\
\left(\mathrm{ml} \times 4 \mathrm{~min}^{-1}\right)\end{array}$ & $4.12 \pm 0.30$ & $2.09 \pm 0.18^{* *}$ & $2.08 \pm 0.21^{* *}$ \\
\hline $\begin{array}{l}\text { Saliva protein concentration } \\
\left(\mathrm{mg} \times \mathrm{ml}^{-1}\right)\end{array}$ & $0.93 \pm 0.05$ & $1.30 \pm 0.09^{* *}$ & $1.05 \pm 0.08$ \\
$\begin{array}{l}\text { Saliva IgA concentration } \\
\left(\mu \mathrm{g} \times \mathrm{ml}^{-1}\right)\end{array}$ & $530 \pm 37$ & $577 \pm 59$ & $562 \pm 75$ \\
\hline $\begin{array}{l}\text { Saliva protein IgA } \\
\text { Concentration }\left(\mu \mathrm{g} \times \mathrm{mg}^{-1}\right)\end{array}$ & $611 \pm 57$ & $567 \pm 96$ & $523 \pm 51$ \\
\hline
\end{tabular}

${ }^{*} \mathrm{p}<0.01,{ }^{* *} \mathrm{p}<0.001$, change from pre-race.

\section{Results}

Forty of 45 subjects completed $90 \mathrm{~km}$, and 31 (22 males, 9 females) completed the $160-\mathrm{km}$ race event (race time, $27.0 \pm 0.4 \mathrm{~h}$ ). Sixty-nine percent of subjects finished the 160 - $\mathrm{km}$ race, the same proportion reported for all race competitors. Data from the 31 finishers are presented in Tables $\mathbf{1 - 5}$, and Fig. 1. Subject characteristics in Table $\mathbf{1}$ indicate that this group of ultramarathoners was highly experienced, having trained for
Table 4 Plasma cytokines $(\mathrm{N}=31)($ mean $\pm \mathrm{SE})$

\begin{tabular}{lccc}
\hline Variable $(\mathbf{p g} / \mathbf{m l})$ & Pre-race & $\mathbf{9 0 - k m}$ & $\mathbf{1 6 0 -} \mathbf{k m}$ \\
\hline IL-10 & $4.65 \pm 0.40$ & $39.7 \pm 8.0^{* *}$ & $49.0 \pm 8.2^{* *}$ \\
\hline IL-1ra & $229 \pm 14$ & $2330 \pm 421^{* *}$ & $1616 \pm 255^{* *}$ \\
\hline IL-6 & $1.19 \pm 0.15$ & $58.6 \pm 4.6^{* *}$ & $60.9 \pm 9.4^{* *}$ \\
\hline IL-8 & $6.31 \pm 1.09$ & $20.4 \pm 2.1^{* *}$ & $22.0 \pm 2.4^{* *}$ \\
\hline${ }^{*} \mathrm{P}<0.01,{ }^{* *} \mathrm{P}<0.001$, change from pre-race. & & \\
& & & \\
& & & \\
\end{tabular}

Table 5 Plasma oxidative stress parameters and total plasma antioxidant potential $(\mathrm{N}=31)($ mean $\pm \mathrm{SE})$

\begin{tabular}{lcll}
\hline Variable & Pre-race & $\mathbf{9 0 - k m}$ & $\mathbf{1 6 0 - k m}$ \\
\hline F $_{2}$-isoprostane $(\mathrm{pg} / \mathrm{ml})$ & $44.4 \pm 2.0$ & $76.6 \pm 9.0^{* *}$ & $59.0 \pm 7.0^{*}$ \\
\hline Lipid hydroperoxide $(\mu \mathrm{M})$ & $7.62 \pm 2.01$ & $13.0 \pm 2.8^{*}$ & $14.4 \pm 3.1^{* *}$ \\
\hline FRAP† & $501 \pm 11$ & $612 \pm 14^{* *}$ & $641 \pm 23^{* *}$ \\
\hline
\end{tabular}

${ }^{*} \mathrm{p}<0.05,{ }^{* *} \mathrm{p}<0.01$, change from pre-race.

$\dagger$ Ferric reducing antioxidant potential, expressed as UM ascorbic acid equivalents.

long distance races for an average of $15 \mathrm{y}$, and competed in over 50 ultramarathon events. Male and female runners did not differ significantly in race time or any of the other variables in Table 1 except for age ( $48.7 \pm 1.4$ vs. $42.9 \pm 2.0 \mathrm{y}$, respectively), body mass (73.0 \pm 1.4 vs. $51.3 \pm 1.4 \mathrm{~kg}$, respectively), and height $(1.78 \pm 0.01$ vs. $1.59 \pm 0.02 \mathrm{~m}$, respectively).

Plasma volume did not change significantly during or immediately after the race (data not shown), and body mass was maintained near pre-race levels (Table $\mathbf{1}$ ). Subjects experienced a strong neutrophilia (249\% increase) and monocytosis (214\%) (Table 2). The blood eosinophil count decreased 58\% from prerace levels.

The total 4-min volume of saliva produced during and following the race event fell by nearly half compared to pre-race levels (Table 3). Salivary IgA concentration and sIgA relative to protein concentration did not change, but the sIgA secretion rate decreased significantly from $508 \pm 40 \mu \mathrm{g} / \mathrm{min}$ pre-race, to $287 \pm 39 \mu \mathrm{g} / \mathrm{min}$ at $90-\mathrm{km}$, and $254 \pm 30 \mu \mathrm{g} / \mathrm{min}$ post-race $(50 \%$ decrease) in the 31 athletes completing the race, and at a similar rate in the 40 athletes completing at least $90 \mathrm{~km}$ but not finishing the race (Fig. 1).

Significant increases were measured in cytokines at $90-\mathrm{km}$ and post-race (Table 4). Post-race, IL-10 increased 9.5-fold, IL-1ra 6.1-fold, IL-6 50.2-fold, and IL-8 2.5-fold over pre-race levels. Post-race indicators of oxidative stress, $\mathrm{F}_{2}$-isoprostane and lipid hydroperoxides, increased $33 \%$ and $88 \%$, respectively (Table $\mathbf{5}$ ). $\mathrm{F}_{2}$-isoprostane was $73 \%$ and $33 \%$ above pre-race levels at $90-\mathrm{km}$ and post-race, respectively. Post-race levels of FRAP were $28 \%$ above pre-race levels. 


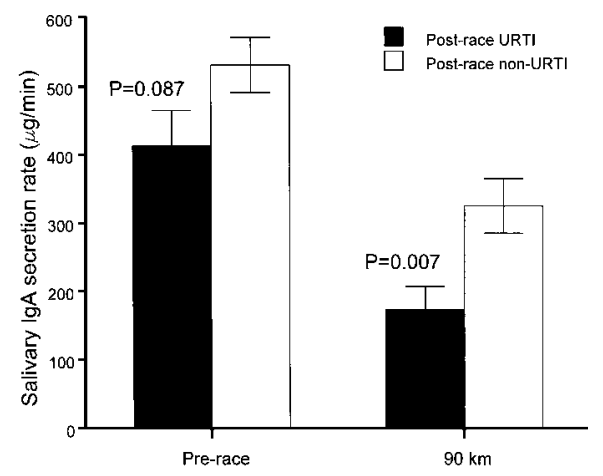

Pearson product-moment correlations revealed modest correlations at $90-\mathrm{km}$ between $\mathrm{F}_{2}$-isoprostane and IL-6 $(\mathrm{r}=0.31$, $\mathrm{p}=0.048), \operatorname{IL}-10(\mathrm{r}=0.31, \mathrm{p}=0.050)$, and IL-8 $(\mathrm{r}=0.43, \mathrm{p}=0.005)$, but no other significant relationships between immune and oxidative stress indicators at $90-\mathrm{km}$ and post-race. Post-race, the correlation between $\mathrm{F}_{2}$-isoprostane and IL-10 was $\mathrm{r}=0.33$, $\mathrm{p}=0.081$.

In the group of runners completing at least $90 \mathrm{~km}(\mathrm{~N}=40)$ of the race, $26 \%$ reported an URTI episode during the two-week period post-race. A low sIgA secretion rate at $90-\mathrm{km}$ was the only immune or oxidative stress measure that differed significantly between post-race URTI and non-URTI groups, $173 \pm 34 \mu \mathrm{g} / \mathrm{min}$ compared to $325 \pm 40 \mu \mathrm{g} / \mathrm{min}$, respectively, $\mathrm{p}=0.007$ (Fig. 2). Pre-race sIgA tended to be lower in runners who reported postrace URTI compared to those not reporting URTI ( $413 \pm 52 \mu \mathrm{g} / \mathrm{min}$ compared to $531 \pm 40 \mu \mathrm{g} / \mathrm{min}$, respectively, $\mathrm{p}=0.087$ ) (Fig. 2). Males and females did not differ significantly in post-race URTI incidence or any of the oxidative stress or immune measures except for pre-race ( $560 \pm 38 \mu \mathrm{g} / \mathrm{min}$ compared to $358 \pm 52 \mu \mathrm{g} / \mathrm{min}$, respectively, $\mathrm{p}=0.011$ ) and post-race sIgA secretion rates $(293 \pm 39 \mu \mathrm{g} / \mathrm{min}$ compared to $163 \pm 23 \mu \mathrm{g} / \mathrm{min}$, respectively, $p=0.008$ ). Age was not related to any of the oxidative stress or immune measures except for a positive correlation with postrace salivary $\operatorname{IgA}$ secretion rates $(r=0.55, p=0.002)$, and prerace IL-6 $(\mathrm{r}=0.38, \mathrm{p}=0.015)$ and pre-race IL-10 $(\mathrm{r}=0.31$, $\mathrm{p}=0.054)$.

Lipid hydroperoxides and $\mathrm{F}_{2}$-isoprostane were not significantly correlated with each other or FRAP at $90-\mathrm{km}$ or post-race. Positive, significant correlations $(\mathrm{p}<0.05)$ at both $90-\mathrm{km}$ and postrace were found for blood neutrophil counts with IL-10 and IL1ra (but not IL-6 or IL-8).

\section{Discussion}

The data from this study confirm our hypothesis and earlier findings with runners competing in marathon and ultramarathon events: the pattern of change in most immune measures is not influenced by gender or age [18-20,22,25]. We did find lower post-race salivary IgA secretion rates in female runners, and in younger runners, but this was not a consistent finding across all time points. The $160-\mathrm{km}$ Western States Endurance Run is regarded as one of the most arduous organized running events in the United States, yet the magnitude of change in immune meas- ures is similar to what we have reported following competitive $42.2-\mathrm{km}$ marathon events $[18,20,25]$.

About one in four ultramarathon runners reported an URTI episode during the two-week period post-race. A low sIgA secretion rate prior to the race and at $90-\mathrm{km}$ was the only immune or oxidative stress measure that differed between URTI and non-URTI groups. Despite lower pre- and post-race sIgA secretion rates in the female runners, incidence of post-race URTI did not differ between male and females. In a prior study of 98 runners competing in a competitive $42.2-\mathrm{km}$ marathon run, we reported that the pattern of change in all saliva measures did not differ significantly across age or gender groups [18]. Seventeen percent of the runners developed URTI during the 15-d period following the marathon race event, and the 1.5 -h post-race saliva IgA: protein ratio, but not sIgA concentration or secretion rate, was lower in runners reporting URTI compared to those who did not $\left(254 \pm 30\right.$ and $388 \pm 26 \mu \mathrm{g} \times \mathrm{mg}^{-1}$, respectively, $\left.\mathrm{p}=0.002\right)$. Attempts to relate sIgA changes after exercise to the incidence of URTI have met with varying success, and studies differ as to which sIgA measure (concentration of sIgA, concentration of sIgA relative to total protein concentration, and $\operatorname{sigA}$ secretion rate) best predicts URTI $[9,10,30,32]$. Tomasi et al. [32] was the first to suggest that a temporary IgA deficiency on the mucosal surface might lead to an increased susceptibility of acquiring viral and bacterial infections during the interval following strenuous exercise. Part of the problem in relating sIgA changes to URTI is that a relatively large subject pool is needed because only a small proportion of endurance athletes become sick following competitive events [18,21].

Cytokines are low molecular-weight proteins and peptides which help control and mediate interactions among cells involved in immune responses [23]. In many instances, individual cytokines have multiple biological activities, and different cytokines can also have the same activity, which provides for functional redundancy within the inflammatory and immune systems. We and others have shown that prolonged, intensive exercise increases the plasma concentration of four cytokines: IL-1 ra, IL-6, IL-8, and IL-10 [17,19, 20, $22-25,31]$. IL-1ra is a powerful inflammatory inhibitor of IL-1, a critical early mediator of the inflammatory and overall immune response. IL-6 is a multifunctional cytokine expressed by many different types of cells that regulates the immune response, hematopoiesis, the acute phase response, and inflammation. The current view is that IL-6 exerts anti-inflammatory effects, although it may promote inflammation in certain circumstances [8]. IL-8 also has multiple functions, is produced by a wide variety of cell types, and is classified as a chemokine because it operates as a granulocyte and T-lymphocyte chemotactic protein [31]. IL-10 is produced by several types of cells including activated macrophages, and functions as an immune system down-regulator, inhibiting the synthesis of several cytokines including IL-1, IL-6, and IL-8 [11]. IL-10 is crucial in limiting inflammatory responses. Thus most of the cytokines present in the plasma during heavy and prolonged exertion are anti-inflammatory $[20,23,31]$.

Although inflammation is an important homeostatic mechanism that limits the effects of infectious agents, inflammation itself has the potential for inducing damage and must be controlled. 
Glucocorticoids and catecholamines, stress hormones that reach high levels during prolonged, intensive exercise, inhibit the production of proinflammatory cytokines, whereas they stimulate the production of anti-inflammatory cytokines, such as IL-10 $[20,23]$. Thus, systemically, an excessive immune response, through activation of the stress system, stimulates an important negative feedback mechanism, which protects the organism from an "overshoot" of proinflammatory cytokines and other products of activated macrophages with tissue-damaging potential. The data from this study and others indicate a strong anti-inflammatory milieu in the blood compartment of athletes that builds within the first few hours and remains at a somewhat constant level for as long as the endurance event lasts (e.g, 327 h) $[20,23,24,31]$.

Oxidative stress may regulate certain aspects of immune function during disease and immunosenescence $[6,8,16,26]$, and act as one mediator of inflammation by inducing apoptosis of leukocytes [29] and biosynthesis of inflammatory cytokines [8,11]. Little is known regarding the link between oxidative stress and immune changes induced by heavy exertion. In mice, lymphocyte damage after exhaustive running has been related to oxidative damage in lymphoid tissues [3]. A link between oxidative stress and suppression of cellular immunity has been described in men following intense, short bouts of exercise [33]. In a previous study, we reported a weak but significant correlation between $\mathrm{F}_{2}$-isoprostane and IL-10 following an $80-\mathrm{km}$ ultramarathon [19], a finding confirmed in the present study in runners at the $90-\mathrm{km}$ aid station when oxidative stress was at its highest level. Redox- and oxidant-mediated pathways play a role in the expression, distribution, and functional properties of IL-10, and this cytokine may emerge as an important link between oxidative stress and inflammatory processes during intensive and prolonged exercise [11].

At higher altitudes, oxidative stress may be greater than similar efforts at sea level. Possible factors include decreased partial pressure of oxygen in inspired air, resulting in greater dependence on anaerobic energy pathways, and increased ultraviolet light intensity $[2,27]$. Our findings of increased $\mathrm{F}_{2}$-isoprostane and lipid hydroperoxides are indicative of increased oxidative stress. These observations are similar to those we have previously reported in an ultramarathon race [19]. Mastaloudis et al. [13] found increased $\mathrm{F}_{2}$-isoprostane following endurance exercise, although the running time was only $2.5 \mathrm{~h}$, while Schmidt et al. [27] found that lipid hydroperoxides were increased following extended training at moderate altitude. Lipid hydroperoxides originate primarily from oxidation of omega- 3 and omega- 6 fatty acids found in lipoproteins, and $\mathrm{F}_{2}$-isoprostane from arachidonic fatty acids esterified in phospholipid [16,26].

Plasma FRAP values were significantly elevated during and following exercise. This increase in antioxidant potential is primarily due to increasing uric acid and vitamin $\mathrm{C}$ in the blood during exercise $[13,19]$. Despite the fact that FRAP values increased, this increase was either insufficient or unable to suppress increased lipid peroxidation. Although, we observed no correlations between oxidative stress and FRAP, total plasma antioxidant potential has been found to be related to oxidative stress in some disease states [28].
In summary, athletes competing in the $160-\mathrm{km}$ Western States Endurance Run experienced large perturbations in blood immune cell counts, inflammatory cytokines, salivary IgA secretion rate, and indicators of oxidative stress. In general, these alterations were similar for male and female runners, and we did not find that the age range of the subjects influenced results. A modest correlation was found between $\mathrm{F}_{2}$-isoprostane and three inflammatory cytokines during the race, suggesting that oxidative stress plays some role in regulating inflammation during heavy exertion. Finally, a low sIgA secretion rate prior to the race and at $90-\mathrm{km}$ was the only immune or oxidative stress measure that differed between URTI and non-URTI groups, lending further evidence for the use of this measure in predicting illness in endurance athletes.

\section{Acknowledgements}

Supported by a grant from the medical board of the Western States Endurance Run, and by NIH grants DK48831, CA77839, and GM15431. Jason D. Morrow is the recipient of a Burroughs Wellcome Fund Clinical Scientist Award in Translational Research.

\section{References}

${ }^{1}$ Allesio H, Hagerman AE, Fulkerson BK, Ambrose J, Rice RE, Wiley RL. Generation of reactive oxygen species after exhaustive aerobic and isometric exercise. Med Sci Sports Exerc 2000; 32: 1576-1581

2 Askew E. Work at high altitude and oxidative stress: antioxidant nutrients. Toxicology 2002; 180: 107-119

${ }^{3}$ Azenabor AA, Hoffman-Goetz L. Intrathymic and intrasplenic oxidative stress mediates thymocyte and splenocyte damage in acutely exercised mice. J Appl Physiol 1999; 86: $1823-1827$

${ }^{4}$ Benzie IFF, Strain JJ. The ferric reducing ability of plasma (FRAP) as a measure of "antioxidant power": The FRAP assay. Anal Biochem 1996; 239: 70-76

${ }^{5}$ Bradford MM. A rapid and sensitive method for the quantitation of microgram quantities of protein utilizing the principle of protein-dye binding. Anal Biochem 1976; 72: 248-254

${ }^{6}$ de la Fuente M. Effects of antioxidants on immune system aging. Eur J Clin Nutr 2002; 56: 5-8

${ }^{7}$ Dill DB, Costill DL. Calculation of percentage changes in volumes of blood, plasma, and red cells in dehydration. J Appl Physiol 1974; 37: $247-248$

${ }^{8}$ Esposito K, Nappo F, Marfella R, Giugliano G, Giugliano F, Ciotola M, Quagliaro L, Ceriello A, Giugliano D. Inflammatory cytokine concentrations are acutely increased by hyperglycemia in humans: role of oxidative stress. Circulation 2002; 106: 2067-2072

${ }^{9}$ Gleeson M, Hall ST, McDonald WA, Flanagan AJ, Clancy RL. Salivary IgA subclasses and infection risk in elite swimmers. Immunol Cell Biol 1999; 77: $351-355$

${ }^{10}$ Gleeson M, McDonald WA, Pyne DB, Clancy RL, Cripps AW, Francis JL, Fricker PA. Immune status and respiratory illness for elite swimmers during a 12-week training cycle. Int J Sports Med 2000; 21: $302-307$

${ }^{11}$ Haddad JJ, Fahlman CS. Redox- and oxidant-mediated regulation of interleukin-10: an anti-inflammatory, antioxidant cytokine. Biochem Biophys Res Commun 2002; 297: 163 - 176

12 Ji LL. Exercise-induced modulation of antioxidant defense. Ann N Y Acad Sci 2002; 959: 82 - 92

${ }^{13}$ Mastaloudis A, Leonard SW, Traber MG. Oxidative stress in athletes during extreme endurance exercise. Free Radic Biol Med 2001; 31: $911-922$

${ }^{14}$ McAnulty SR, McAnulty LS, Nieman DC, Dumke C, Utter AC, Morrow JD, Henson DA, Proulx WR, George GL. Effect of blueberry phytochemicals and vitamin $C$ on oxidative stress and immune changes following exercise in the heat. Free Radic Res: in press 
${ }^{15}$ Mooren F, Lechtermann A, Fromme A, Thorwesten L, Volker K. Alterations in intracellular calcium signaling of lymphocytes after exhaustive exercise. Med Sci Sports Exerc 2001; 33: $242-248$

${ }^{16}$ Morrow JD, Roberts LJ. The isoprostanes: Unique bioactive products of lipid peroxidation. Prog Lipid Res 1997; 36: 1 - 21

${ }^{17}$ Nieman DC. Immune response to heavy exertion. J Appl Physiol 1997; 82: $1385-1394$.

${ }^{18}$ Nieman DC, Henson DA, Fagoaga OR, Utter AC, Vinci DM, Davis JM, Nehlsen-Cannarella SL. Change in salivary IgA following a competitive marathon race. Int J Sports Med 2002; 23: 69-75

${ }^{19}$ Nieman DC, Henson DA, McAnulty SR, McAnulty L, Swick NS, Utter AC, Vinci DM, Opiela SJ, Morrow JD. Influence of vitamin C supplementation on oxidative and immune changes following an ultramarathon. J Appl Physiol 2002; 92: 1970-1977

${ }^{20}$ Nieman DC, Henson DA, Smith LL, Utter AC, Vinci DM, Davis JM, Kaminsky DE, Shute M. Cytokine changes after a marathon race. J Appl Physiol 2001; 91: 109-114

${ }^{21}$ Nieman DC, Johansen LM, Lee JW, Cermak J, Arabatzis K. Infectious episodes in runners before and after the Los Angeles Marathon. J Sports Med Phys Fit 1990; 30: 316- 328

${ }^{22}$ Nieman DC, Peters EM, Henson DA, Nevines EI, Thompson MM. Influence of vitamin $C$ supplementation on cytokine changes following an ultramarathon. J Interferon Cytokine Res 2000; 20: 1029-1035

23 Ostrowski K, Rohde T, Asp S, Schjerling P, Pedersen BK. Pro- and antiinflammatory cytokine balance in strenuous exercise in humans. J Physiol 1999; 515(Pt 1): $287-291$

${ }^{24}$ Ostrowski K, Schjerling P, Pedersen BK. Physical activity and plasma interleukin- 6 in humans - effect of intensity of exercise. Eur J Appl Physiol 2000; 83: $512-515$

${ }^{25}$ Pistilli EE, Nieman DC, Henson DA, Kaminsky DE, Utter AC, Vinci DM, Davis JM, Fagoaga OR, Nehlsen-Cannarella SL. Influence of age on im- mune changes in runners after a marathon. J Aging Physical Activity 2002; 10: $432-442$

${ }^{26}$ Roberts LJ, Morrow JD. Products of the isoprostane pathway: unique bioactive compounds and markers of lipid peroxidation. Cell Mol Life Sci 2002; 59: $808-820$

${ }^{27}$ Schmidt MC, Askew EW, Roberts DE, Prior RL, Ensign WY, Hesslink RE. Oxidative stress in humans training in a cold, moderate altitude environment and their response to a phytochemical antioxidant supplement. Wilderness Environ Med 2002; 13: 94-105

${ }^{28}$ Sofic E, Rustembegovic A, Kroyer G, Cao G. Serum antioxidant capacity in neurological, psychiatric, renal diseases and cardiomyopathy. J Neural Transm 2002; 109: 711 - 719

29 Splettstoesser WD, Schuff-Werner P. Oxidative stress in phagocytes"the enemy within". Microsc Res Tech 2002; 57: 441 - 455

${ }^{30}$ Steerenberg PA, van Asperen IA, van Nieuw Amerongen A, Biewenga A, Mol D, Medema GJ. Salivary levels of immunoglobulin A in triathletes. Eur J Oral Sci 1997; 105: 305-309

${ }^{31}$ Suzuki K, Yamada M, Kurakake S, Okamura N, Yamaya K, Liu Q, Kudoh S, Kowatari K, Nakaji S, Sugawara K. Circulating cytokines and hormones with immunosuppressive but neutrophil-priming potentials rise after endurance exercise in humans. Eur J Appl Physiol 2000; 81: $281-287$

${ }^{32}$ Tomasi TB, Trudeau FB, Czerwinski D, Erredge S. Immune parameters in athletes before and after strenuous exercise. J Clin Immunol 1982; 2: $173-178$

${ }^{33}$ Vider J, Lehtmaa J, Kullisaar T, Vihalemm T, Zilmer K, Kairane C, Landor A, Karu T, Zilmer M. Acute immune response in respect to exercise-induced oxidative stress. Pathophysiology 2001; 7: 263-270

34 Vina J, Gomez-Cabrera M, Lloret A, Marquez R, Minana JB, Pallardo FV, Sastre J. Free radicals in exhaustive exercise: Mechanisms of production, and protection by antioxidants. IUBMB Life 2000; 50: 271-277 